\title{
Trange as a resource for ethnic and cultural identity: experience of Latvian expats in Sweden
}

\section{Maruta Pranka}

Institute of Philosophy and Sociology, University of Latvia, E-mail: pranka@latnet.lv https://orcid.org/0000-0002-3836-2379

\section{Ilze Koroḷeva}

Institute of Philosophy and Sociology, University of Latvia, E-mail: ilze.koroleva@lu.lv

https://orcid.org/0000-0002-7701-5775

\section{Ginta Elksne}

Institute of Philosophy and Sociology, University of Latvia, E-mail: ginta.elksne@lu.lv

https://orcid.org/0000-0003-1011-3351

Rezumat

\footnotetext{
Abstract

The aim of this article is to investigate the experience and significance of the use and preservation of Latvian for native language maintenance, national culture and identity in the Nordic countries. This has been done by analysing native (heritage) language as a resource for ethnic and culture identity. The aim of the article is to ascertain the language situation in the diaspora, explore practices and perspectives regarding the sustaining of Latvian language and ethnic culture. From the theoretical point of view, the data is approached with reference to $P$. Bourdieu's view on language skills as linguistic capital, a form of culture capital. The paper uses a combination of both quantitative survey and in-depth interviews with Latvian emigrants, especially those in the Nordic countries.
}

Scopul acestei lucrări este de a analiza experiența și semnificația utilizării și conservării limbii letone în vederea menținerii limbii materne, culturii naționale și identității țărilor nordice. Acest lucru a fost realizat prin analiza limbii materne (moștenite) ca resursă pentru identitatea etnică și culturală. Scopul lucrării este de a analiza situația lingvistică din diaspora, de a explora practicile și perspectivele cu privire la susținerea limbii și culturii etnice letone. Din punct de vedere teoretic, datele sunt interpretate având ca punct de reper viziunea lui $P$. Bourdieu asupra competențelor lingvistice privite drept capital lingvistic, ca o formă de capital cultural. Lucrarea folosește o combinație de anchete cantitative și interviuri aprofundate cu emigranții letoni, în special cu cei din țările nordice. 
Keywords: cultural capital, heritage language, language and identity, migration

CC BY-SA License (https://creativecommons.org/licenses/by-sa/2.0)

This paper has been presented at the Twelve International Conference on Baltic and Nordic Studies in Romania: ReThinking multiculturalism, multilingualism and cultural diplomacy in Scandinavia and the Baltic Sea Region, hosted by the Romanian Association for Baltic and Nordic Studies, May 27-28, 2021.

This research is funded by the Latvian Council of Science: Project "Exploring Well-Being and Social Integration in the Context of Liquid Migration: A Longitudinal Approach", project No. lzp. -2018/1- 0042 and project "Narrative Perspectives on Intergenerational Transmission of Memory", project No. lzp-2018/1-0458.

\section{Introduction}

Following World War II, around 120000 Latvians went into exile, with 4500 of them settling in Sweden. According to various sources, the overall number of Latvian refugees in Sweden in 1945 was 3418, whereas the total number of Latvians in Sweden in 1945 was $5-6,5$ thousand. ${ }^{1}$. Researchers have usually referred to this wave of emigration as the "exile" wave, honoring the title given by the migrants themselves and highlighting the forced character of the mass flight, which occurred in response to the Soviet reoccupation of Latvia. The most influential figures in Latvia's culture, education, science, and politics were purposely evacuated to Sweden by boat near the end of WWII. As a result, a sizable section of the intellectual and political elite arrived in Sweden, and their share, when compared to other refugees, was most certainly higher than in the Latvian diaspora elsewhere in the globe. Many life story interview narrators still refer to the extensively represented Latvian elite in Sweden when describing the Latvian community in Sweden as unique and distinct from Latvian communities in other areas of the world. ${ }^{2}$ A new historical phase of emigration from Latvia, including emigration to Sweden, began following restoration of the independence of Latvia in 1991 and still continues to this day.

The terms "migration" and "emigration" refer to population migration patterns triggered by a variety of factors, and the terms "refugee"

\footnotetext{
${ }^{1}$ National Encyclopedia: https://enciklopedija.lv/skirklis/21049

2 Baiba Bela, "Latviskās identitātes saglabāšana, tālāknodošana un tās dažādība," in Mēs nebraucām uz Zviedriju, lai kḷūtu par zviedriem: Zviedrijas latviešu dzīvesstāsti. ed. B. Bela (Rīga: Zinātne, 2010), 15-44
} 
and "exile" refer to people who are neither guest workers or immigrants. "Immigrant" denotes a voluntary change of residence, but "refugee" and "exile" denote a forced relocation, as well as a different attitude toward oneself and one's own area than immigrants, as well as distinct adaption models to the host community ${ }^{3}$.

Over the last century, Latvia has experienced many waves of emigration and immigration. After 1991 Latvia became one of the most mobile European nations - a typical "sending country". It was among the hardest hit by the crisis resulting in unprecedented rates of emigration. Since the beginning of the 21st century, Latvia has lost $9.1 \%$ of its population (OECD 2013). People are increasingly opting to relocate their entire family to another country with the intention of remaining there permanently. In addition, recent trends show that families more frequently decide to emigrate with their children and plan to stay abroad permanently.

Figure 1. Long term population migration (1990-2020)

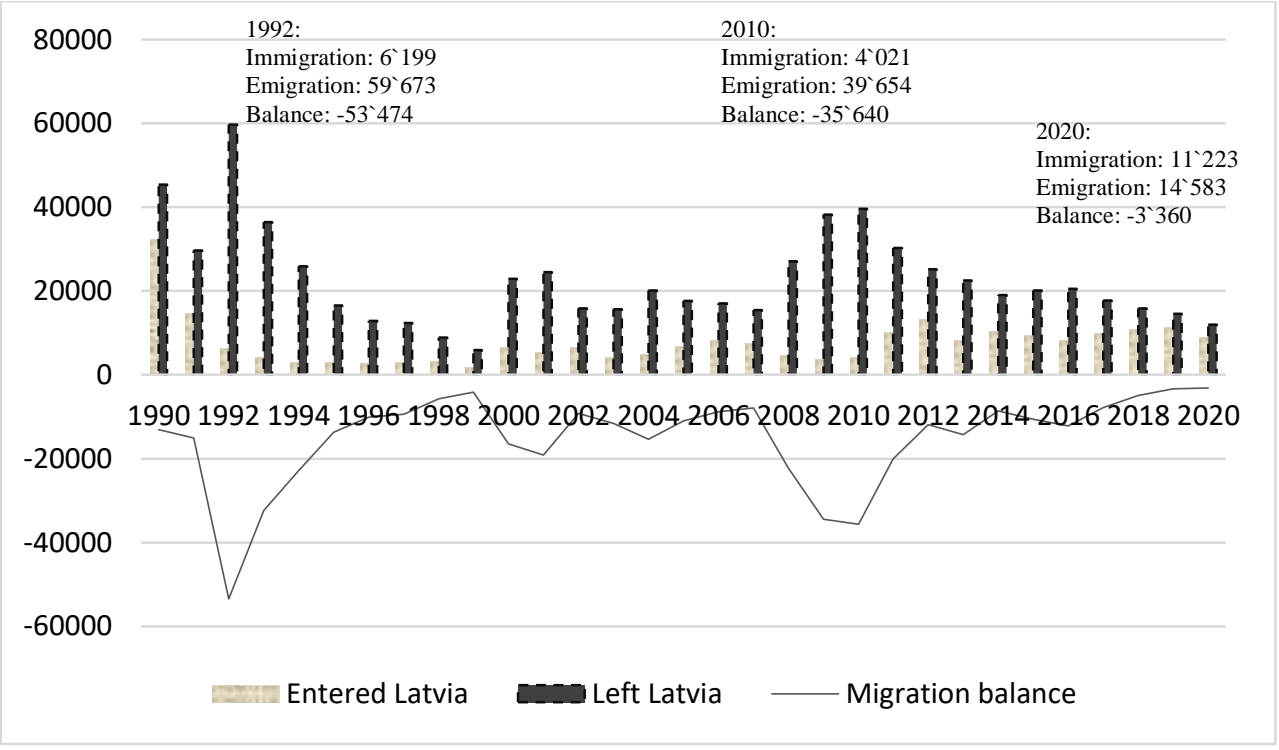

Source: Central Statistical Bureau of Latvia

\footnotetext{
${ }^{3}$ Bela 2010
} 
The data compiled by the Central Statistical Bureau of Latvia show long-term migration from Latvia and to Latvia from 1990 to 2020, as well as the migration balance, which is the difference between migration and immigration. The most significant number of emigrants leaving Latvia was in 1992. Many individuals left Latvia because USSR military troops and their families fled willingly and in accordance with international agreements. Furthermore, many individuals who had immigrated to Latvia during the USSR's existence left for their now independent countries, the former USSR republics. In the following years, migration data gradually stabilized. However, with the onset of the economic crisis in 2008, and especially in 2009, migration rates soared, while immigration rates plummeted. Emigration rates fell in the years after that, while immigration rose, and this trend has continued in recent years. The migration balance, on the other hand, remains negative.

Migration to the Nordic countries has surged in recent decades as well. According to Bureau of Citizenship and Migration Affairs in Republic of Latvia official data regarding officially registered Latvian nationals abroad in 2006, 146 Latvian nationals were registered in Finland but on 1 January 2021 this number already totalled 1658. Also, Norway during the last years has become attractive for economic migration: the officially registered number of nationals from Latvia has increased from 155 persons in 2006 to 5362 at the beginning of 2021. With this number, Norway has even overtaken the traditional migration destination for Latvia - Sweden - where at the beginning of 2006, 1489 Latvian nationals were officially registered, but at the beginning of 2021 they numbered 5191. Although the true extent of migration most likely differs from that number and is higher, the chart reveals the dynamics of migration from Latvia to the Nordic countries over the past 15 years.

The emigrant community in Sweden differs from other Latvian diaspora communities due to the geographic proximity to Latvia as well as historically common links. Many Latvians have taken advantage of the opportunity to work as guest workers in Sweden while also remaining in exile for various reasons. Since Latvia regained its independence, Latvians 
from Sweden have been able to actively engage in both Latvian and Swedish cultural and social life.

Figure 2. Emigration flows to Nordic countries

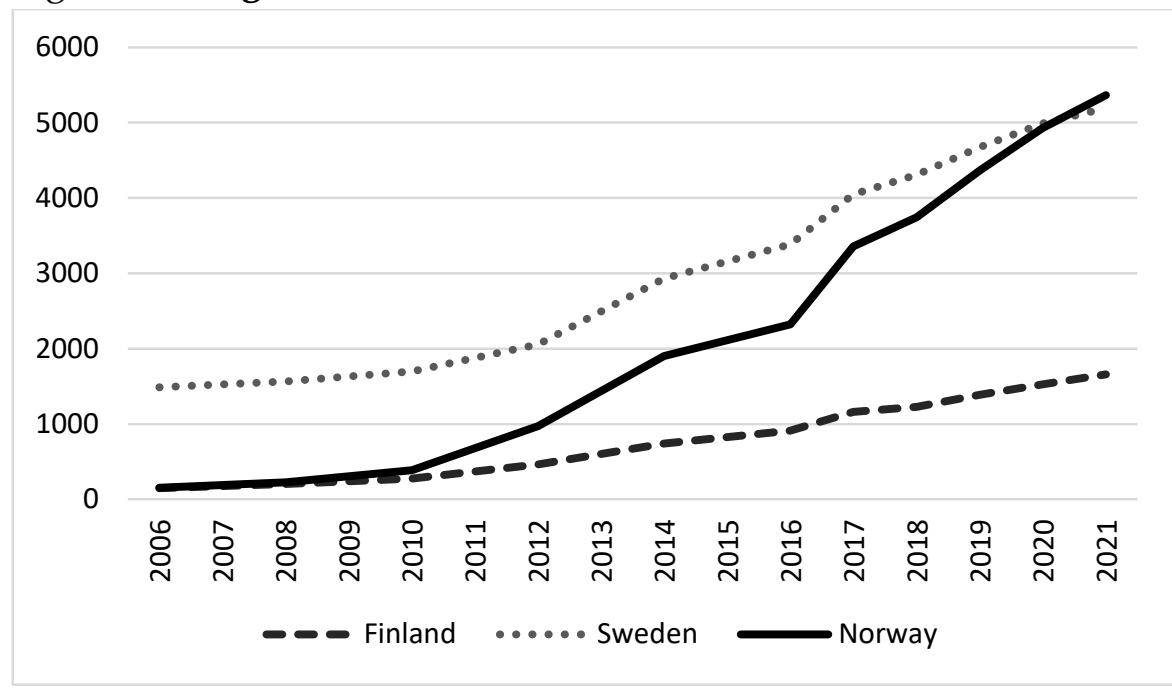

Source: Office of Citizenship and Migration Affairs of Latvia

Study aims and research questions

The aim of this paper is to explore the experience and significance of the use and preservation of the Latvian language for the maintenance of the native language, national culture and identity outside Latvia, analysing factors which affect the use of native (heritage) language in the emigrant community in the Nordic countries, especially in Sweden.

\section{Methodology and data}

Quantitative data from two waves of a large-scale longitudinal survey of Latvian emigrants and a survey of panel respondents on language use issues in the diaspora have been used to generally characterize the use of the Latvian language and significance of the language in the maintenance of one's own ethnic identity and forming of the identity of children. The first wave of the survey was conducted in 2014 (total number of responses in the final data set was 14048 respondents from 118 countries, of these 1089 - from 
the Nordic countries) ${ }^{4}$, in 2019 in the second wave survey, 56242 respondents were reached (of these 1053 from the Nordic countries). ${ }^{6}$ In the longitudinal survey of panel respondents in 2020, 1452 respondents participated - parents who live together with minor children?

In order to deepen the understanding of Latvian language usage abroad, life stories and in-depth interviews with Latvians living in emigration collected in the Latvian National Oral History archive were used. The collection consists of audio interviews, mainly conducted as life stories. Over the course of the research, the National Oral History collection has recorded more than 4700 memory stories. ${ }^{8}$ The word 'national' indicates that the collection belongs to the state of Latvia, regardless of the ethnicity, nationality or country of residence of the narrator of the memory.

More than sixty life-story interviews with Latvians in exile and twenty life-story interviews with respondents who emigrated from Latvia after the restoration of independence in 1991 are recorded and selected for the purposes of the study. The overall aim is to obtain comprehensive information on people who have left Latvia in recent decades and on the Latvian diaspora in general. The names of some respondents in the text have

\footnotetext{
${ }^{4}$ Quantitative survey within the framework of the ESF project "The Emigrant Communities of Latvia: National Identity, Transnational Relations, and Diaspora Politics" (sample size $\mathrm{n}=$ 14048 respondents from 118 countries)

${ }^{5}$ Quantitative survey within the framework of Latvian Council of Science project "Exploring Well-Being and Social Integration in the Context of Liquid Migration: A Longitudinal Approach" sampling 6242 Latvian nationals living outside Latvia.

${ }^{6}$ To correct for the self-selection bias inherent in the sampling design, sampling weights have been applied. The sampling weight of each respondent is inversely proportional to that respondent's estimated conditional sample inclusion probability, given the following characteristics: (1) geographical area of residence, (2) sex, (3) age, (4) level of education, and (5) main language. Reference data have been compiled from multiple sources, including Eurostat, OECD's International Migration Database (IMDB) and Database on Immigrants in OECD countries (DIOC), data from Latvia's Office of Citizenship and Migration Affairs, and data from the main recipient countries' national statistics offices. The distributions of the socio-demographic characteristics (2)-(5) have been computed separately for each geographical area. Due to only marginal distributions being available within each area, a raking algorithm has been applied. See: https://migracija.lv/

${ }^{7}$ The project finansed by the Latvian Language Agency "Latvian language in the diaspora:

Exploration of the situation".

${ }^{8}$ See also: https://mutvarduvesture.lv/en/
} 
been changed to ensure the confidentiality of data. The text of each interview is indicated by an abbreviation, where "NMV" refers to the collection of the National Oral History archive, followed by a reference to the serial number of the interview in the collection.

\section{Theoretical Basis}

Preservation of the Latvian language and culture in the diaspora is defined as one of the main tasks of diaspora policy. As Daina Grosa, researcher at the University of Latvia, points out, "The Diaspora Law gives the Latvian language a significant role in the diaspora in connection with the Latvian identity of the diaspora, preservation (maintenance) and acquisition of the language (mostly for children), and the law includes support measures and actions that the Latvian state should take in order to implement diaspora policy tasks." 9 This is especially important for those Latvians who live abroad with small children and want to maintain their Latvian language and identity.

Pierre Bourdieu qualifies language skills as linguistic capital, a type of cultural capital. It is inherited or mastered over time; it affects habitus. According to Bourdieu, cultural capital has the same value as economic and social capital. Cultural capital, including linguistic capital is mainly transferred in the family. Although in the case of children capital in its different forms is mainly inherited from their parents it can be obtained also in other ways ${ }^{10}$. Cultural capital for the next generation is handed over via different pedagogic activities of a family - education in its broadest sense, the value of which depends on differences between forced pedagogic activities and pedagogic activities accepted by the family and cultivated in different groups and social classes ${ }^{11}$.

\footnotetext{
${ }^{9}$ Daina Grosa, 'What Language is Spoken in the Diaspora? The Dynamics of the Language Situation', Academic Life, 56 (2020): 46-54

${ }^{10}$ Pierre Bourdieu, Language and Symbolic Power (Cambridge: Polity Press, 1991)

${ }_{11}$ Pierre Bourdieu and Jean-Claude Passeron, Reproduction in education, society and culture, (Thousand Oaks, CA: Sage Publications, Inc., 1990)
} 
Cultural capital "is knowledge, skills and other benefits such as education or technical qualifications"12. Linguistic capital as a part of cultural capital has an invaluable influence on educational achievement. Bourdieu and Passeron emphasize that language is not only an instrument of communication: together with its richer or poorer collection of words it provides a greater or smaller complex of categories, in this way being able to decipher and swiftly operate with complex structures, and this largely depends on the language passed down in the family ${ }^{13}$. But the value of the capital depends on the context. As the context changes, its values can be revised, overestimated. When changing the country of residence, emigrating - the mother tongue/ native language may lose its value as linguistic capital, as an individual enters the country with another dominant language.

According to Bourdieu, language as symbolic power is extremely important for symbolic struggles within various social hierarchies that migrants enter into - on the one hand, in the population of migrants, and on the other, in the host society's relationship with the local population ${ }^{14}$. Adsera and Pytlikova emphasize a proper language competence as the main factor that influences the differences between migrants regarding the level of education, income and their social status, for example, if in their new place of residence they experience inclusion or exclusion in different social spheres ${ }^{15}$.

In academic research and in the everyday context, the term 'heritage language' is used to refer to the maintenance of the mother tongue outside the country of origin. This term refers to non-dominant languages spoken by minorities living in a country ${ }^{16}$. According to Rothman, a language qualifies as the heritage language if it is a language spoken at home or otherwise easily

\footnotetext{
12 Bourdieu 1991

${ }^{13}$ Bourdieu and Passeron 1990

${ }^{14}$ Abdelmalek Sayad, The Suffering of the Immigrant (Cambridge: Polity Press, 2004)

15 Alicia Adsera and Mariola Pytlikova, 'The role of language in shaping international migration', The Economic Journal, 125(586), (2015): F49-F81

${ }^{16}$ Nelleke Van Deusen-Scholl, 'Toward a definition of heritage language: sociopolitical and pedagogical considerations', Journal of Language, Identity \& Education, 2(3), (2003): 211-230
} 
accessible to children, and in general that this language is not the dominant language of society ${ }^{17}$.

Speakers of a heritage language are offspring of immigrants in their first or second generation who have a connection to the heritage language, even though the prevalent everyday language is the host country's language. According to Montrul, the speakers of the heritage language know this language and maintain it on various levels, but often their knowledge of the heritage language is not complete ${ }^{18}$. For speakers of the mother tongue, this language is the first one if we speak about the order in which the language was acquired, but for the most part it is the secondary language since it dominates less in their lives and fades with time ${ }^{19}$. Although heritage languages are usually referred in the narrower sense - as the language used at home, while in the surrounding environment the dominant language is another language, often English, however the heritage language in a broader sense emphasizes the linguistic heritage connection with the acquisition of cultural heritage. ${ }^{20}$

The preservation and loss of heritage language is influenced by various factors, which fall into two categories: the individual level and the group level. Individual level factors include a person's age, gender, place of birth, education, marital status, reason for migration, length of stay in the host country, prior knowledge of the dominant language and linguistic diversity in the host country. Group-level factors include the size and dispersion of the ethnic group in the home country, the state language policy, and the linguistic differences of the native language from the majority language. ${ }^{21}$

\footnotetext{
${ }^{17}$ Jason Rothman, 'Understanding the nature and outcomes of early bilingualism: Romance languages as heritage languages', International Journal of Bilingualism, 13(2), (2009): 155-163

${ }_{18}$ Silvina Montrul, 'Dominant language transfer in adult second language learners and heritage speakers', Second Language Research. Special Issue: Selective first language influence and retreat from negative transfer, 26 (3), (2010): 293-327

${ }^{19}$ Maria Polinsky and Olga Kagan, 'Heritage Languages: In the 'Wild' and in the Classroom', Language and Linguistics Compass 1(5), (2007): 368-395

${ }^{20}$ Polinsky and Kagan 2007

${ }^{21}$ Sandra Kipp, Michael Clyne and Anne Pauwels, Immigration and Australia's language resources (Canberra: Australian Government Publishing Service, 1995)
} 
Knowledge of the language of the host country is one of the key skills for successful integration. In turn, knowledge of the mother tongue is an important dimension of ethnic identity and belonging. The interrelationship between language and ethnicity is characterized by identification with a particular cultural community. This belonging to a particular cultural community and the degree to which people identify themselves as members of a cultural community can take many levels, from deep involvement to denial of belonging.

Studies show that language transfer is better in childhood than language maintenance among adolescents and young adults ${ }^{22}$. The most important factors contributing to the preservation of the mother tongue of immigrant children are parents who speak their mother tongue at home, with friends of the same ethnic background and supportive ethnic networks. In the immigrant environment the desire to teach the children their native language dominates, transfer of the native culture and positive interrelation of this aspect in the family and the practical use of the language at home is one of strongest factors of maintenance and preservation of a heritage language ${ }^{23}$. Besides some communities motivate children to learn their inherited language, emphasizing not only the necessity to maintain one's culture and identity, but also possible economic gains for users of this language ${ }^{24}$.

Research shows the close link between national identity and language and argues that it is constructed through language. The development of national identity goes hand in hand with social integration and language acquisition, and by learning the language of the new home country, migrants can more successfully internalize their values, traditions and culture ${ }^{25}$. Family links, participation in different rituals, cultural

\footnotetext{
${ }^{22}$ Olena Nesteruk, 'Heritage language maintenance and loss among the children of Eastern European immigrants in the USA', Journal of Multilingual and Multicultural Development, 31 (3), (2010): 271-286

${ }^{23}$ Nesteruk 2010

${ }^{24}$ Chloe Diskin, 'New Speakers in the Irish Context: Heritage Language Maintenance Among Multilingual Migrants in Dublin, Ireland', Frontiers in Education, 4, Article 163, (2020): 1-7

${ }_{25}$ Daiga Kamerāde and Ieva Skubiṇa, "Growing Up to Belong Transnationally: Parent Perceptions on Identity Formation Among Latvian Emigrant Children in England", In The
} 
practices and activities are the main resources for maintaining an understanding about the ethnic identity and a sense of home and belonging in transnational families ${ }^{26}$. Both previous research ${ }^{27}$, and experience of the authors of the article show that along with the parental contribution, an important role in maintenance of the heritage language and transfer of culture is played also by the possibility to get an education in schools which provide training in the heritage language. In the acquisition of a heritage language, also making use of ethnic community resources plays an important role. The assistance of churches, community centres and other organisations provide access to the heritage language in schools, day centers and heritage language acquisition classes.

Using Anthony Giddens' concept of "ontologic security"28, a person can feel safe when they experience sense, order, continuity and stability, which creates a feeling of control. While in emigration, parents try to seek this ontologic security characterized by Giddens for themselves and to ensure it for their children. Concentrating on family experience, Strathclyde University professor Daniela Sime analyzes the stress which migration causes in family relations, emotional disturbances and the threat to individual feelings of belonging and ontologic safety, at the same time emphasizing the inner (in)security, the perceptions of which change with time due to the family situation, uncertainty ${ }^{29}$. Researchers indicate the fragility of the balance between economic gains as result of immigration and the "sacrifices" with regard to the emotional "fee/ payment" that most often is identified with loss of contacts with children and family members, loss of

\footnotetext{
Emigrant Communities of Latvia: National Identity, Transnational Belonging, and Diaspora Politics, eds. R. Kaša and I. Mieriņa (SpringerOpen, 2019), 145-162c identity

${ }^{26}$ Harry Goulbourne, Tracey Reynolds, John Solomos, and Elisabetta Zontini, Transnational Families: Ethnicities, identities and social capital (London: Routledge, 2011)

27 See Nesteruk 2010

28 Anthony Giddens, Modernity and Self-Identity: Self and Society in the Late Modern Age (Cambridge: Polity Press, 1991)

${ }^{29}$ Daniela Sime, 'Belonging and Ontological Security Among Eastern European Migrant Parents and Their Children', Central and Eastern European Migration Review, 7(1), (2018): 35-53
} 
social support networks that unequivocally influences the individual satisfaction, level of subjective wellbeing ${ }^{30}$.

The research data of Latvian emigrant communities show that the children's future, educational opportunities, and access to more comprehensive healthcare facilities have all played a role in the ultimate choice to emigrate. ${ }^{31}$. Financial security is regarded as a precondition for the safety of the entire family, with the assumption that emotional security will follow. However, financial and material security do not always outweigh the emotional uncertainty experienced by children who have been separated from their relatives. ${ }^{32}$. Parents believe it is their responsibility to compensate for their children's feelings of insecurity in emigration by providing a different kind of safety - material well-being - as well as attempting to ensure that their children retain their native language, culture, and feelings of belonging to their ethnic country while also learning the culture of the host country.

The desire of emigrants to maintain their ethnic identity and mother tongue as a value may conflict, especially among the younger generation, with the desire to adapt to the dominant, i.e. host country culture, language environment.

\section{Results and discussion:}

\section{Role of the family in maintaining Latvian language}

According to survey data from previous research of Latvian emigrants, the main key to maintaining Latvian language skills in emigration and for children not to lose their heritage language or learn the language of their parents or ancestors (in reference to children born outside Latvia and

\footnotetext{
30 Sime 2018 \& Zlatko Skrbiš, 'Transnational Families: Theorising Migration, Emotions and Belonging', Journal of Intercultural Studies, 29(3), (2008): 231-246

31 Mihail Hazan, "Emigration from Latvia in the 21 century Latvian Emigrant's Communities", in Latvijas emigrantu kopienas: Cerību diaspora, ed. Mierina I. (Rīga: LU FSI, 2015), 11-25; Andris Saulītis and Inta Mierina, “(Ne)pastāvošās Latvijas emigrantu kopienas ASV", in Latvijas emigrantu kopienas: Cerību diaspora, ed. I. Mieriṇa (Rīga: LU FSI, 2015), 161179

32 Sime 2018
} 
learning Latvian as a foreign language), it is critical that parents use the Latvian language in the family. ${ }^{33}$. In this case, parents play the most significant role in their children's language learning, and they bear the greatest responsibility in the process of recognizing Latvian's worth. Time spent emigrating, on the other hand, has a detrimental impact on the maintenance of the Latvian language or the degree of knowledge retained outside Latvia.Moving to live or living for a longer period of time outside the heritage country, a person has to find new resources for belonging, to seek and form new identities, to fit in the environment and society, which is hard to imagine without learning the host country language, or at least learning some of the foreign languages. Thereby usage and maintenance of the Latvian language impose an additional load both in the form of psychological, social and economic challenges experienced by many emigrants. This particularly applies to children who usually learn the language of the host country more easily and more rapidly than their parents and language skills at this age grow rapidly, while the level of heritage language use diminishes proportionally. The longitudinal survey data of emigrants show that even over the five years between the two survey waves, in emigrant Latvian families the number of Latvians who use only Latvian in their family has decreased significantly (from $40 \%$ to $28 \%$ ), while the number of Latvians who use both Latvian and another language in their family has increased (from $24 \%$ to $32 \%$ ). Among emigrants of all nationalities, including Latvian emigrants, over the past five years the number of children whose level of Latvian is very poor or even non-existent has increased significantly. That without a doubt indicates that families in the diaspora experience challenges or will experience even more challenges in the future in order to maintain the Latvian language and transfer a sense of Latvian identity to their children.

\footnotetext{
33 Inta Mieriṇa, “Bērnu valodu prasme un latviešu valodas zudums/zuduma intensitāte jaunajās mìtnes zemēs", $\quad$ https://migracija.lv/publikacijas/b\%C4\%93rnu-valodu-prasme-unlatvie $\%$ C5\%A1u-valodas-zudums-zuduma-intensit $\%$ C4\%81te-jaunaj $\%$ C4\%81sm\%C4\%ABtnes-zem\%C4\%93s/2016, accessed 01.09.2021
} 
Figure 3. Conversational languages at home: changes in using Latvian language within the family, $2014-2019$

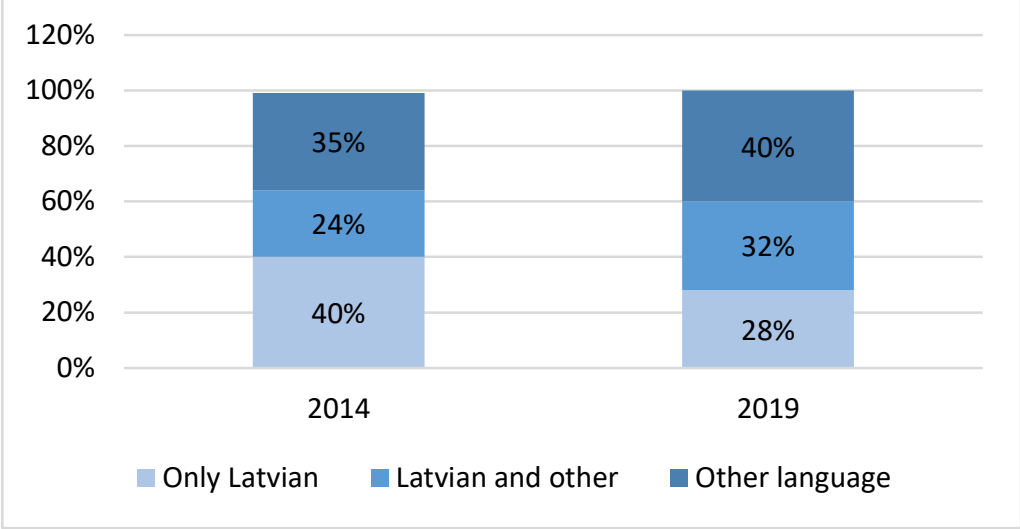

Source: The authors, based on longitudinal data from emigrant surveys in 2014 and 2019.

Statistics and research show that the Latvian diaspora characteristically has many transnational families, where maintenance of the Latvian language poses a special challenge ${ }^{34}$. It is characteristic among emigrants from Latvia - notwithstanding their nationality and age - to have a good level of knowledge of several languages. Figure 4 . shows that many families also use several conversational languages at the same time. Interestingly, the Nordic countries in comparison with other countries also represented by Latvian emigrants have more families where Latvian is used as a language of conversation in the home, and these families are also twice more likely to use the language of the host country. Sweden is most worthy of mention, where Latvian as the conversational language is used in $56 \%$ families of emigrants, but the language of the host country the Swedish language is used in $27 \%$ families. It can be explained both with the previously mentioned history of emigration and traditions, social and demographic characteristics of emigrants. The geographical proximity of both states is particularly beneficial to the preservation of Latvian, allowing for stronger interactions and contacts with one's nation

\footnotetext{
${ }^{34}$ Mierina 2016
} 
of origin, as well as more regular opportunities to visit Latvia.Also, Latvian skills of the children differ depending on the region - Latvian is mastered best by children who live in the diaspora in the Nordic countries, United Kingdom, in North America.

Figure 4. Languages of communication in the family, \%

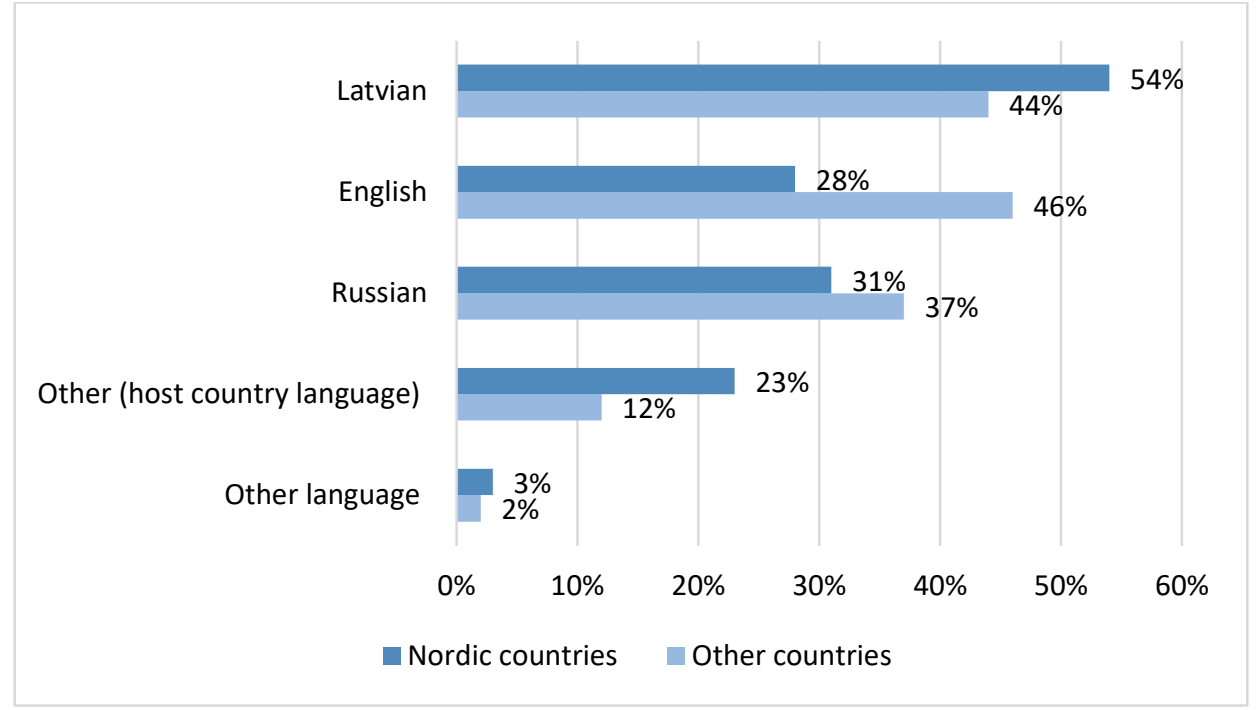

Source: The authors, based on emigrant survey, 2019 (n=6242).

\section{Attitudes toward maintaining the Latvian language}

The use of the native language daily while living in a foreign country is not the simple skill of knowing this language. For individual survival, especially to support a family in this situation it is extremely important to know the language of the host country. People continue to use their native language in a foreign country because it is important for them, but not necessary for survival. ${ }^{35}$

Latvia as a state actively encourages the acquisition of the Latvian language through its Diaspora policy, with significant assistance for diaspora schools and summer schools, for example. As language plays a crucial role in the transmission of ethnic culture and the formation of identity

\footnotetext{
${ }^{35}$ Bela 2010
} 
in emigration, one of the most important aspects is the use of the Latvian language in the family; and especially - the attitude of parents towards teaching Latvian to their children. In order to preserve the Latvian language and strengthen Latvian identity in the diaspora, the motivation of parents and the desire to teach their children this language, to promote the acquisition and use of the language are important.

Parents are concerned about the preservation of the Latvian language in emigration, both in the previous exile emigration wave and in the current emigration wave, and are working to do so in a variety of ways. Time has passed and we no longer have direct access to extensive data on older Latvians in exile; however, some trends show that parents face similar problems regardless of the time period. Therefore, we look at the data from quantitative surveys to shed more light on the trends in parents' views on preserving the Latvian language in emigration; and how these views change over a longer period.

Data from quantitative surveys according to the Parents attitude towards children`s knowledge of Latvian show that most parents living in exile want their children to understand and speak Latvian. In addition, parental attitudes remain relatively constant over time. As in 2014, approximately $68 \%$ of parents want their children to be fluent in Latvian. But the proportion of parents who would like their child to understand and be able to communicate in Latvian at least at the conversational level has even increased slightly (from $22 \%$ to $28 \%$ ).

Research data show that one of the most important reasons why parents think it is important for a child to know Latvian is the need to communicate with family and friends from the country of origin (see Figure 5). In the Nordic countries (especially in Sweden - 84\%) more often than in other countries, respondents mention the necessity to communicate with family as a main motive for learning the Latvian language. It can be explained both by maintaining relationships and, more importantly, by the regularity with which members of the Nordic diaspora visit Latvia why they outperform responders from other countries. (see Figure 6). 
Figure 5. Why is it important for Latvian parents that their child knows Latvian: comparison of Nordic and other countries

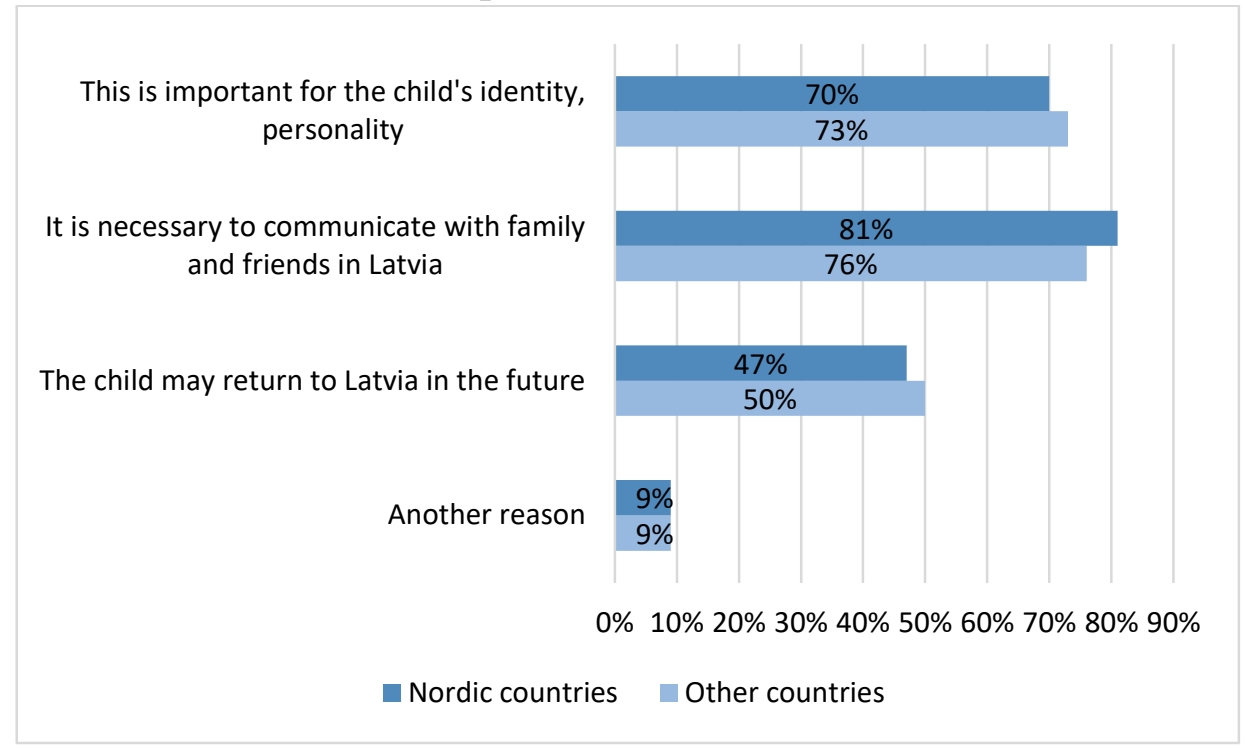

Source: The author, based on a longitudinal panel survey, 2020. Parents living together with their minor children $(n=1452)$.

In the context of the problems discussed, it should be noted in particular that almost as many parents (73\%) believe that the Latvian language is important for the development of a child's personality and identity. Looking ahead from the perspective of the nation of origin, it is encouraging that almost one-half of parents mention the possibility of their children returning to Latvia. There are no statistically significant differences between the mentioned motives for the importance of language skills depending on whether the child was born in Latvia or abroad. Parents of children born in Latvia slightly more often than others mention the preservation of identity $(76 \%)$ and consider the idea of a return to Latvia (52\%), while when talking about children born abroad, parents more often (79\%) believe that language is important for the child to be able to communicate with grandparents, relatives and friends in Latvia. 
This is well illustrated by respondents' comments in open-ended answers in the quantitative survey: "The child must know and respect the land from which his roots come!"; "It is an important part of Latvianness", "Necessary to understand our culture, history"; "To understand the language of the mother's heart and soul"; "It is important to me that my children understand and feel me; and to understand and feel me to the depths of my heart is possible only in Latvian!"

Figure 6. Frequency of visiting Latvia, \%

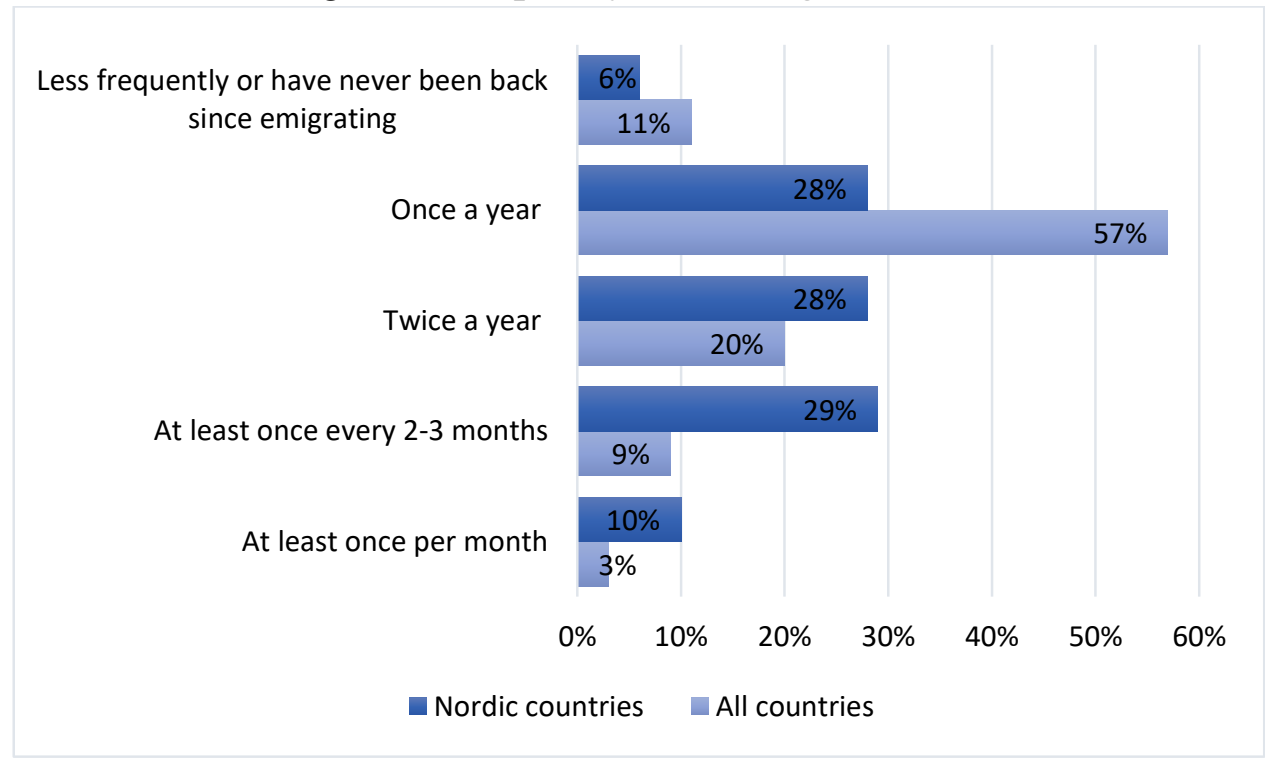

Source: The authors, based on emigrant survey, 2019 ( $n=6242)$.

Comparing the data of the 2014 and 2019 emigrant surveys, the most popular activity to strengthen children's Latvian language at home and their identity in the diaspora was the acquisition of Latvian at home (see Figure 7). Over five years the number or children who learn Latvian at home and who read books in Latvian has significantly decreased. Although diminishing of these activities is not statistically significant, however if in 2014 every third child could read Latvian books, then in 2019 only every fourth child in emigration could do so. 


\section{Figure 7. Activities for maintaining the Latvian language in emigration}

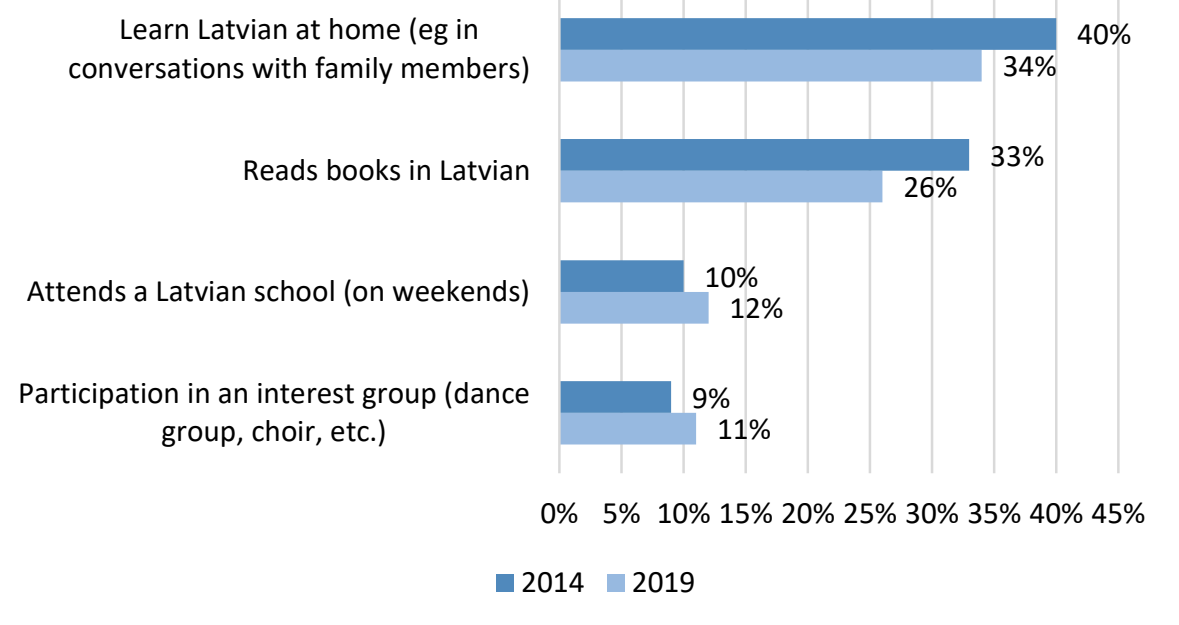

Source: The author, based on longitudinal panel survey, 2020. Parents, who live together with minor children. $(n=1452)$.

The crucial role of the family in maintenance of the Latvian language and identity was highlighted also in exile representatives' life stories. A significant activity mentioned in almost all interviews was the regular participation of the whole family in Latvian community activities. For children of exiles who now speak and understand Latvian and actively participate in Latvian diaspora life, parents were regularly involved in their activities and sent their children to Saturday schools and summer camps the little ones were regularly taken to Saturday school and summer camp, but the older ones played theatre, danced, sung in a choir, participated in sports activities, and were taken to visits to Latvia. ${ }^{36}$.

Aija (born in Latvia, in 1942), went to Sweden as a young child of refugees. She grew up in Sweden, and remembers that as a child she resisted the Latvianness imposed on her by her parents (or so it seemed to her):

"We had "the terror" of the Latvian language at home. I'm laughing now... When I started going to the gymnasium, my dad was mindful that, say, history, geography, I had to retell it to him in Latvian. What I was taught

\footnotetext{
${ }^{36}$ Bela 2010
} 
at school, what was assigned for the next day, I had retell it to him in Latvian. [..] As a teenager, Latvian society seemed terribly boring to me...[..] Latvia was so unreal." (NMV - 4393)

Aija undergoes a change when she reads a novel of the same title as her name - Aija - in Latvian. The novel "Aija" by the Latvian writer Jaunsudrabiňš is a poetic description of the first love (and its break up, of course), with Latvian rural life in the background. Aija read it at the age of fourteen. And after reading this book (it should be noted that the language of the book is not easy), she acquires a deeper sense of Latvian identity. Initially, the desire to resist her parents' efforts to maintain Latvianness also prevails.

Ausma (born in 1946) also remembers, she resisted her parents' efforts to maintain Latvianness. She liked to sing Latvian songs, she liked to participate in Latvian cultural events, but she did not feel a deeper attraction to Latvia. She has grown up in a family with Latvian traditions and interest in Latvian culture. The family spoke Latvian, had constant cultural contacts which were maintained with other Latvians. On the other hand, the family was well integrated in Sweden: Anna, Ausmas ' mother, was a respected and highly-regarded doctor in Sweden, receiving an order of merit for her work. Ausma remembers:

"For those who live in Sweden, it depends on how thorough the parents were. Because, however, our generation resisted our parents: What is this nonsense that the parents are talking about, we are in Sweden ... I perceived that as well. As it seems to me, not too many continued to live as we did. We all enjoyed our cultural life. Singing Latvian songs. Yes, we all liked that. That's so important." (NMV-2529)

When Ausma visited Latvia for the first time, already after regaining of independence, she did not expect any special reaction, but suddenly she felt a sense of belonging to Latvia. "I belong here, here is my [home] country!", she says. And she added that her son, half a Swede, also said: "Latvia is the most beautiful country." (NMV-2529)

Gundars (born in 1953) grew up in a bilingual environment, he remembers that the Swedish, or the environment of his friends was supposedly separated from the Latvian - family, environment. He 
remembers: "I grew up with two languages, Swedish and Latvian. We spoke Latvian in the family. I learned Swedish at school. There were a few Swedish families in the neighbourhood, but it was more like a mix. But there were also pure families of Swedish origin. ... I can't say that I've always had a lot of friends because it was like a severance. Latvian was spoken at home". (NMV-4609)

Anita (born in 1990) represents the new wave of emigration from Latvia. She left Latvia as a child in the early 2000s, joining her mother, who went to Sweden in search of work, but later started a new family with a local man. Anita's story confirms that both the mother's strong position and close relations with relatives and friends played a major role in preserving the Latvian language and maintaining a sense of belonging; including regular visits to Latvia.

In the interview, Anita reveals: "When I moved [to Sweden], it was a difficult time. I didn't speak [Swedish], I didn't speak English. And everything was new. Mom was very strict. When we were kids, we had to read books to stay in touch with Latvian. [..] My mother did everything to keep the Latvian language. I am also strict in that respect, and when I have children, I also want them to have the Latvian language [...] I have lived in Sweden for 17 years and I still say that I am an immigrant. I have not changed citizenship ${ }^{37}$, we are who we are, and it should not be hidden." (NMV-4564)

Anita's story illustrates that parents' attention to maintaining their heritage language in emigration must be analysed in relation to the forming of the children's identity and family communication with family members left behind.

The immigrant environment is dominated by the desire to teach children their mother tongue, thus facilitating the transfer of native culture and positive interaction in this aspect within the family; and the practical use

\footnotetext{
${ }^{37}$ The interview was held in 2018; and since October 2013 The Citizenship Law allows for citizens of Latvia to have double citizenship with EU, NATO, EEA and other countries. The allocation of a double citizenship was the government's reaction to the growing emigration of Latvians in order to maintain close ties with the diaspora.
} 
of language at home is one of the strongest factors in maintaining inherited language ${ }^{38}$.

\section{Nationality of the spouse}

The ethnicity of the respondent's spouse is an important factor regarding Latvian language use in the family. Both quantitative data and the material in life stories interviews show that the spouse`s attitude to a great extent influences their children's attitude to the heritage language and ethnic identity. In families where both parents are Latvians, the children mostly speak Latvian, in turn in ethnically mixed families the situation may differ.

Anna (born 1974) emigrated in 2004, driven by personal reasons, and wanted to see the world and explore new places. Married in exile, her husband is an immigrant to Sweden from a third country, the family has two children. Anna reveals that the children are very much taught Latvianness language, traditions (children participate in Sunday school activities). The husband also has a positive attitude towards teaching the Latvian language, he learns the Latvian language a bit too. In addition, the husband also teaches his own language so that the children can communicate with relatives of both parents.

In addition to the need to communicate with relatives in Latvia and thoughts about the possible return of children to Latvia in the future, Anna's story also shows the importance of the mother tongue in communication with the child, the opportunity to express the full range of emotions, more accurately share their experiences. Anna is a little worried about the time when the children start school. She understands that the children would have a new, Swedish-speaking environment, and she has to think about preservation of Latvian as well, without creating resentment and resistance to Latvianness by her children.

In the third generation of migrants the most common is integration into the Swedish environment. Thus, the mother of Gundar's daughters is Swedish, the daughters don't speak Latvian although in childhood they understood the Latvian language. Gundars' mother Venta, when talking

\footnotetext{
${ }^{38}$ Nesteruk 2010
} 
about her desire to teach her granddaughters Latvian, remembers that when her granddaughters visited her, they even spoke Latvian with the cats: „How did they understand?" She remembers that never in her life had she spoken with her cats in Latvian. About her daughter in law Venta says: „We have very good contact. But she is Swedish from the Northern part of Sweden and she has her own opinions." (NMV-2533) Regarding the diminishing of Latvianness, Venta explains that this is because Latvians keep together much less. Venta says: "I think that for the younger generation of children it is much harder to maintain Latvianness now. It is much more difficult because there are so few of us and we are distracted. They don't meet Latvians as often. A flock of Latvians don't live together but Latvian additional school still exists." (NMV-2533)

The narrative adds to the experience described by researchers about the loss of heritage language as a process in three generations of European immigration ${ }^{39}$. Representatives of the first generation use the language of the host country, but prefer the use of the native language at home. The representatives of the second generation speak in the language of the host country at school and with friends, more and more frequently replying to their parents in the language of the host country at home, more and more frequently becoming limited bilinguals. The individuals of the third generation lose the knowledge of the first generation's native language because it has no support at home nor any support outside of $\mathrm{it}^{40}$.

The emigrant's choice to maintain the native language mainly depends on the frequency of close daily contacts with grandparents and other relatives. In the interview, Anna, in response to the question "Why did you think it was crucial for the children to speak Latvian?" answers: "The Latvian language was my automatic language, in which I want to talk to my children. I could not imagine talking with my children in English. To speak in a language which I cannot speak properly, say something incorrectly, and be misunderstood. [... If we ever go to Latvia, I want them [children] to speak

\footnotetext{
${ }^{39}$ Fishman, J.A. Language Loyalty in the United States (New York: Arno, 1978)

${ }^{40}$ Nesteruk 2010
} 
the Latvian language, and to talk and understand it. I have both grandmothers and other relatives [in Latvia]." (NMV-4568)

It is not enough to maintain the language abroad with mere good will, an awareness of one's Latvian identity, it often requires both additional time and material resources. Therefore, the attitude of the non-Latvian spouse is especially important. In most cases, however, it must be admitted that the attitude of the spouse towards the use of another (not his / her mother tongue in the family) is quite tolerant. Data show that more than half (54\%) of non-Latvian spouses have a positive view of and even strongly support the use of the Latvian language (at least as one of the languages) in the family, another $26 \%$ do not object, others have a neutral attitude or no interest at all, and only $2 \%$ of spouses do not support or oppose it (see Figure 8). When comparing the attitude of the spouse to the Latvian language in ethnically mixed families, the use of Latvian in the Nordic countries does not significantly differ from the use of Latvian language in families living in Sweden (in 59\% cases the non-Latvian spouse/ spouse who has different ethnicity is very supportive of the use of Latvian in the family, for example in communication with the children).

Figure 8. Spouse's attitude towards the use of the Latvian language in the family

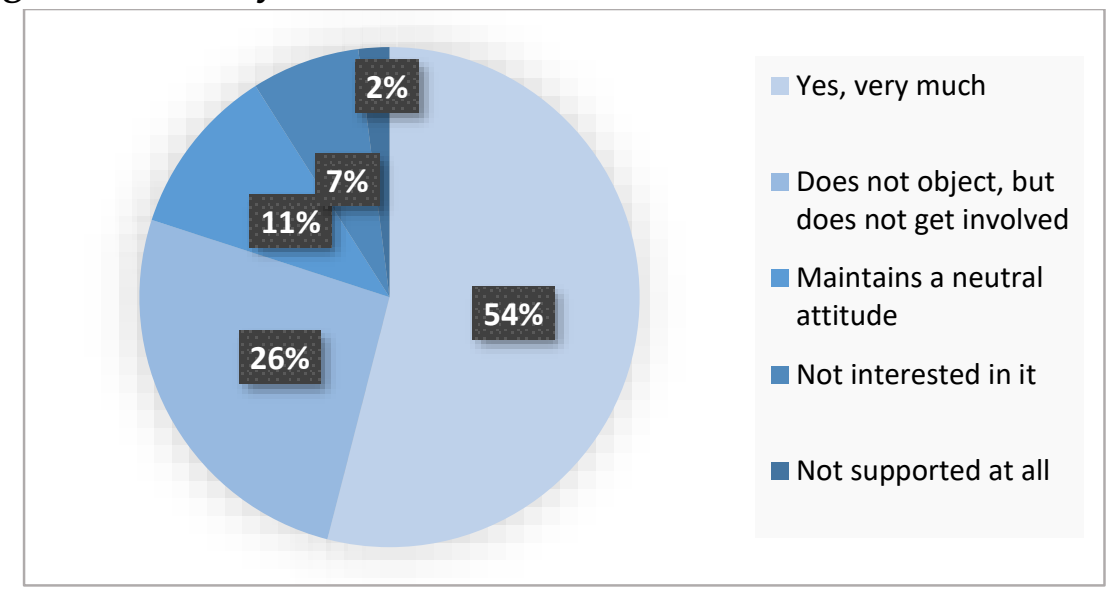

Source: The authors, based on a longitudinal panel survey, 2020. Respondents who have a spouse of another nationality, 2019. 
The data from a quantitative survey of emigrants, show that the most used language in the diaspora families correlates with the nationality of the respondent or his/her spouse, showing once more the conversational role of Latvian language in the family. The fact that the spouse is a non-Latvian, does not contribute to a poorer knowledge of Latvian on its own and the fact that the spouse is Latvian does not improve the knowledge of Latvian on its own, but, observing changes over the past five years we can see that those families in which Latvian was spoken in 2014, have stopped using Latvian most often if their spouse is a citizen of the host country (see Figure 9.). Also those, for whom the link with Latvia and feeling of belonging has diminished, as well as those who do not plan to return to Latvia and emigrants of the Russian population, even those who, prior to emigration, spoke Latvian in family.

\section{Figure 9. Changes in use of the Latvian language depending on the nationality of the spouse, 2014-2019}

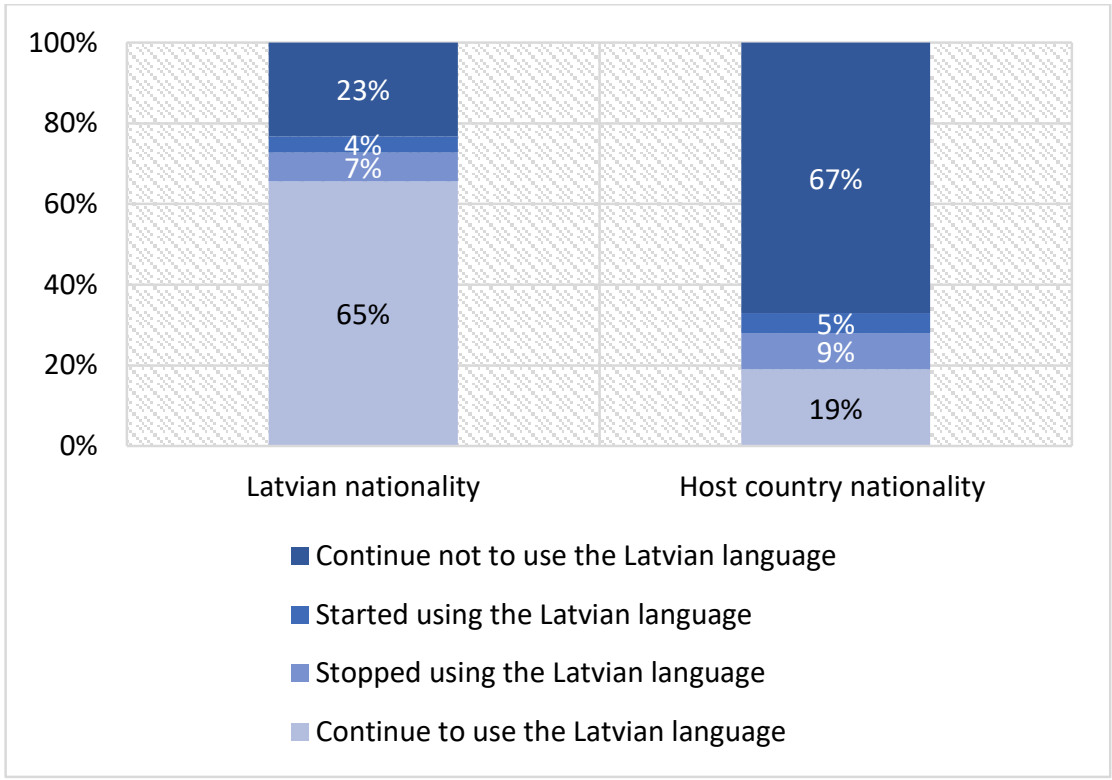

Source: The authors, based on longitudinal data from emigrant surveys in 2014 and 2019. 
It is interesting that in the Nordic countries, in comparison with other countries, if the spouse is a citizen of the host country/ representative of another nationality (see Figure 10) the Latvian language in the family is used more widely.

Figure 10. Language use within the family depending on the spouse's nationality, \%

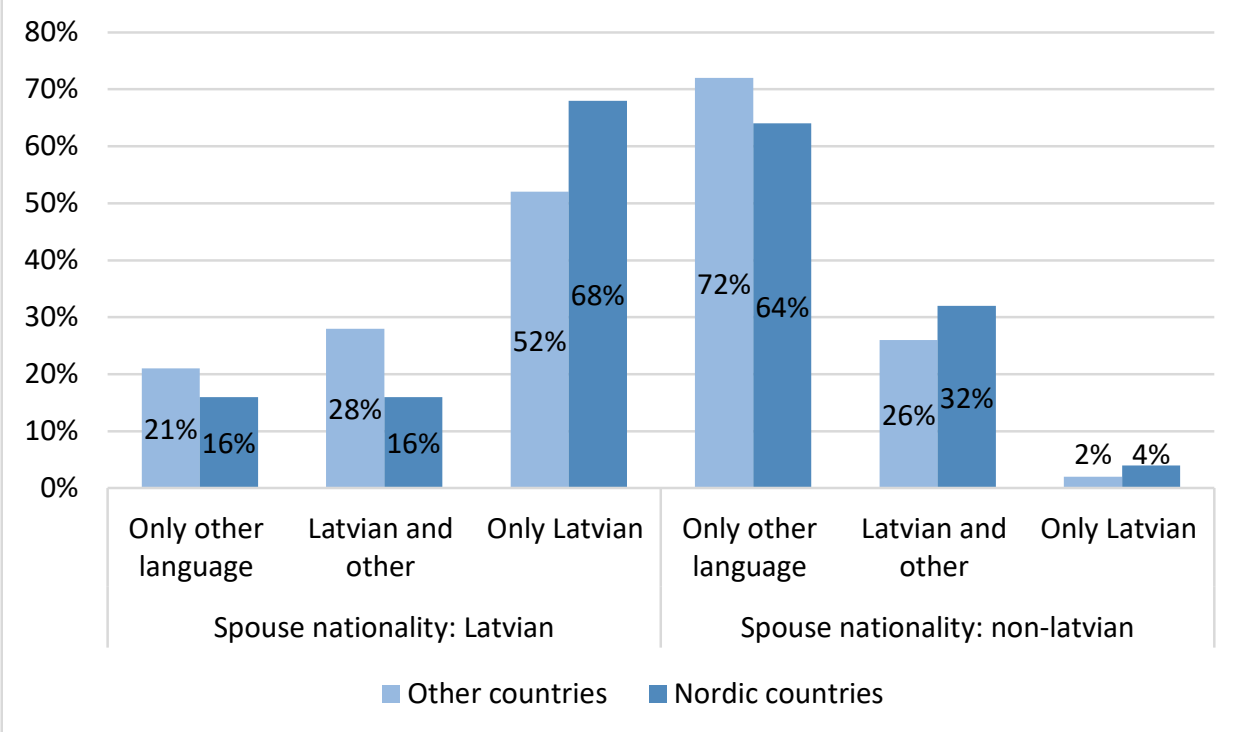

Source: The authors, based on emigrant survey, 2019.

\section{Contradiction between social environment in the host country and family atmosphere}

The desire of emigrants to maintain their ethnic identity and native language as a value may conflict, especially in the youth environment with a desire to adapt to the dominant culture i.e. culture of the host country, language environment: both joining the new home country and desiring not to lose links with the heritage country. Especially as emigrant children grow older, personal and emotional crises can arise when there is a need to choose between two "competing" cultures. Migrant children are often attributed in the literature to a fractured or changing identity, a shared sense of belonging, and a conflicting sense of home. 
Researcher Baiba Bela, analysing the maintenance of ethnic identity among expats and aspects of transmission in life-story interviews, emphasizes: "Life within two cultures is not easy and it offers opportunities to choose one's identity. In many cases, children deliberately moved away from Latvians against their parents' (in mixed families - one of the parents) desires and efforts. The question about the use of Latvian in the family is complicated due to one more cause. As explains one of the narrators, in the 1950s, scientists argued that it is not good for a small child to speak in two languages. Therefore, many parents felt obliged to choose between being good parents and the desire to be good Latvians. So individual families, where both parents are Latvian started to speak Swedish at home. But other families continued to speak Latvian with their children." ${ }^{41}$

Today, as quantitative survey data show, the attitude of parents has changed and a large proportion of parents think that having skills in several languages (knowing Latvian among them) stimulates the child's intellectual development, makes his/her imagination richer, it is of value and an investment into the child's education ${ }^{42}$. More often the problem is resources, the abilities and attitude of parents and children. In any event, it is an added burden for parents who must take their children to Latvian schools, supply educational materials, remind them to study, and inspire the children by example, urging them to feel more comfortable using the language at home every day. For a child, this is something he or she undertakes at home in addition to official schooling in the host country, and it is something they frequently do in their spare time and at the sacrifice of other interests. For children of preschool and especially of school age it is easier and more convenient when communicating to use the language which they use when speaking to friends and which they learn at preschool, or school. A large proportion of diaspora children, when communicating among themselves, use several languages: more than half $(54 \%)$ of the children use Latvian,

\footnotetext{
${ }^{41}$ Bela 2010

${ }^{42}$ Inta Mieriņa, Ilze Koroḷeva, Rasa Jansone, and Daina Grosa, Latviešu valoda diasporā: situācijas izpēte. Analìtisks pārskats par pētījuma rezultātiem (Rīga: LU Filozofijas un sociologijas institūts, 2020)
} 
English is used by $43 \%$, but a third (33\%) use also/or the language of the host country when speaking among themselves.

Quite often children become a kind of intermediary between several cultures ("cultural brokers") to their family because they obtain mandatory education at school, often also learn the language of the host country more quickly and fit into the new society..$^{43}$ About such exile experiences, trying to integrate themselves more quickly into Swedish society, Venta explains in an interview:

"However to learn the language themselves many academics spoke Swedish at home. Children had to go to school straight away, they learned the language first, also pronunciation was correct therefore in order for parents to learn as well at home, the whole family spoke Swedish. It is possible to understand. It is a necessity. You have to use the language of the country that you live in." (NMV-2533).

Emphasizing the value of language as cultural capital and its significance, learning the dominant language ensures the younger generation better success in education and higher competitiveness in the labour market, because language is not only a means of communication, but serves as a symbolic instrument of power, created in a definite context or in a linguistic market, where properties of a market define the value of the linguistic product, valuing some products higher than others ${ }^{44}$. And the dominant language of a host country usually has a higher value or "market".

However Daina Grosa emphasizes that living in the European Union with its open borders we increasingly have to reckon with multilingualism in the family, and calls to accept mobility and a transnational lifestyle not as "a destined loss for those who live in the diaspora of languages of the heritage countries, but rather as an opportunity that those who live in the diaspora should value and pass on" ${ }^{\prime 4}$.

Therefore, parents and society as a whole have the challenge of finding ways to help children adapt to life in an environment with several

\footnotetext{
${ }^{43}$ Daniela Sime and Rachael Fox, 'Home abroad: Eastern European children's family and peer relationships after migration', Childhood, 22(3), (2015): 377-393

${ }^{44}$ Pierre Bourdieu, The Logic of Practice (Cambridge: Polity Press, 1992)

${ }^{45}$ Grosa 2020
} 
languages and cultures, not conflicting with the process of identity formation, how to make learning the language and culture suited to and exciting for Latvian children who were born or have lived outside of Latvia. The solution may be found by combining the efforts of individual families and public support through the implementation of diaspora policy.

\section{Conclusions}

The analysis of the experience of emigrants leads to the conclusion that individuals of Latvian origin both in exile and the more recent emigrants emphasize the special importance of learning the Latvian language for their children as knowledge of the heritage language. It is both an important part of their cultural capital and an important dimension of ethnic identity and belonging.

The main factors affecting the use of native or heritage language in the emigrant community are:

- Family and conversational languages at home, playing the main role for maintaining the Latvian language and identity in children. Our research data correspond with the conclusions of other researchers that emigrants tend to teach children the heritage language and facilitate the transfer of native culture and positive interaction in this aspect within the family; and the practical use of language at home is one of the strongest factors in maintaining an inherited language.

-The ethnicity of the respondent's spouse is an important factor regarding the use of the Latvian language in the family. The Latvian language is used in families with both Latvian parents, but the situation in ethnically mixed families may be different. Nevertheless, as the research data show, the attitude of the non-Latvian spouse to Latvian language use in the family is more tolerant in families living in the Nordic countries, especially in Sweden, than it is in other host countries.

-A close relationship and active communication with relatives in Latvia, especially with grandparents are of great importance according to both the quantitative survey as well data from the indepth interviews. 
-Different activities and events such as singing in choirs, cultural events etc. in Latvian communities in the diaspora provide an important contribution to the maintenance and preservation of heritage language and native culture. These are especially active in Sweden.

The geographical proximity and opportunities for more regular personal interactions with family and friends in the original country can explain the situation of Latvian language and culture preservation in Sweden. Historical traditions, as well as the social and demographic aspects of emigration, could be important influences as well. Although maintenance of the native language is essentially important for preserving national identity and belonging, language knowledge of the host country is one of the key skills for successful integration into the host country, better success in education and competitiveness in the labour market. The desire of immigrants to keep their ethnic identity and heritage language may conflict with this, particularly for young people who want to adapt to the dominant culture and linguistic environment of their new home country.

Emigrant children could experience personal and emotional crises in a situation of choosing between two "competing" cultures. Children could become a kind of "cultural brokers" between two cultures in their families, as they often learn the language of the host country and integrate into the new society more quickly due to compulsory school education. Parents and society face the challenge both of helping a child to adapt to life in a multilingual and multicultural environment without creating conflicts and problems in the process of ethnic identity formation and heritage language and culture preservation. The solution must be found by combining the individual efforts of families, with public support via the implementation of diaspora policy. 


\section{References:}

Adsera, Alicia and Pytlikova, Mariola. The role of language in shaping international migration. The Economic Journal, 125(586), (2015): F49-F81.

Bela, Baiba. Latviskās identitātes saglabāšana, tālāknodošana un tās dažādība. In Mès nebraucām uz Zviedriju, lai kḷūtu par zviedriem: Zviedrijas latviešu dzīvesstāsti. Ed. Bela, B. Rīga: Zinātne, 2010, 1544 .

Bourdieu, Pierre. Language and Symbolic Power. Cambridge: Polity Press, 1991.

Bourdieu, Pierre. The Logic of Practice. Cambridge: Polity Press, 1992.

Bourdieu, Pierre and Passeron, Jean-Claude. Reproduction in education, society and culture (2nd ed.). Thousand Oaks, CA: Sage Publications, Inc., 1990.

Diskin, Chloe. New Speakers in the Irish Context: Heritage Language Maintenance Among Multilingual Migrants in Dublin, Ireland. Frontiers in Education, 4, Article 163, (2020): 1-7.

Fishman, Joshua A. Language Loyalty in the United States. New York: Arno, 1978

Giddens, Anthony. Modernity and Self-Identity: Self and Society in the Late Modern Age. Cambridge: Polity Press, 1991.

Goulbourne, Harry, Reynolds, Tracey, Solomos, John and Zontini, Elisabetta. Transnational Families: Ethnicities, identities and social capital. London: Routledge, 2011.

Grosa, Daina. Kādā valodā runā diaspora? Valodas situācijas dinamika (What Language is Spoken in the Diaspora? The Dynamics of the Language Situation). Akadèmiskā Dzīve, 56, (2020): 46-54.

Hazans, Mihails. Emigrācija no Latvijas 21. gadsimtā reǵionu, pilsētu un novadu griezumā. In Latvijas emigrantu kopienas: Cerību diaspora. Ed. Mierina I. Rīga: LU FSI, 2015, 11-25.

Kamerāde, Daiga and Skubiṇa, Ieva. Growing Up to Belong Transnationally: Parent Perceptions on Identity Formation Among Latvian Emigrant Children in England. In The Emigrant Communities of Latvia: National Identity, Transnational Belonging, and 
Diaspora Politics. Eds. R. Kaša and I. Mieriņa. SpringerOpen, 2019, 145-162.

Kārkliṇa, Ieva and Kamerāde, Daiga. "Nenāc manā istabā, es nesaprotu latviski": Latvijas emigrantu bērnu valodas un identitātes veidošanās. LU FSI, 2015. http://fsi.lu.lv/userfiles/file/ESF_Latvijas_emigrantu_kopienas/Ex -ante/FSI_Karklina_Kamerade_Emigrantu_bernu_valoda.pdf.

Kasinitz, Philip. Becoming American, becoming minority, getting ahead: The role of racial and ethnic status in the upward mobility of the children of immigrants. Annals of the American Academy of Political and Social Science, 620, (2008): 253-269.

Kipp, Sandra, Clyne, Michale and Pauwels, Anne. Immigration and Australia's language resources. Canberra: Australian Government Publishing Service, 1995.

LR Saeima. Diasporas likums. Latvijas Vēstnesis (14.11.2018.) Nr. 225. Acessed: https://likumi.lv/ta/id/302998 (01.09.2021.).

LR Saeima. Pilsonības likums. Latvijas Vēstnesis (11.08.1994.) Nr. 93. Acessed: $\quad$ https://likumi.lv/ta/id/57512-pilsonibas-likums (01.09.2021).

Mannitz, Sabine. Coming of Age as 'The Third Generation': Children of Immigrants in Berlin. In Childhood and Migration: From Experience to Agency. Ed. J. Knörr. Bielefeld: Transcript Verlag, 2005, 23-50.

Mieriña, Inta. Bērnu valodu prasme un latviešu valodas zudums/zuduma intensitāte jaunajās mītnes zemēs. 2016. https://migracija.lv/publikacijas/b\%C4\%93rnu-valodu-prasmeun-latvie\%C5\%A1u-valodas-zudums-zudumaintensit $\%$ C4\%81te-jaunaj $\% C 4 \% 81$ s-m $\% C 4 \%$ ABtneszem $\%$ C4\%93s/

Mieriņa, Inta, Koroḷeva, Ilze, Jansone, Rasa and Grosa, Daina. Latviešu valoda diasporā: situācijas izpēte. Analītisks pārskats par pētījuma rezultātiem. LU Filozofijas un sociologijas institūts, 2020.

Montrul, Silvina. Dominant language transfer in adult second language learners and heritage speakers. Second Language Research. Special 
Issue: Selective first language influence and retreat from nagative transfer, 26 (3), (2010): 293-327

Nesteruk, Olena. Heritage language maintenance and loss among the children of Eastern European immigrants in the USA. Journal of Multilingual and Multicultural Development, 31 (3), (2010): 271-286.

Polinsky, Maria. Incomplete Acquisition: American Russian. Journal of Slavic Linguistics, summer-fall 2006, 14(2), (2006): 191-262.

Polinsky, Maria and Kagan, Olga. Heritage Languages: In the 'Wild' and in the Classroom. Language and Linguistics Compass 1(5), (2007): 368-395.

Rothman, Jason. Understanding the nature and outcomes of early bilingualism: Romance languages as heritage languages. International Journal of Bilingualism, 13(2), (2009): 155-163.

Saulītis, Andris and Mieriņa, Inta. (Ne)pastāvošās Latvijas emigrantu kopienas ASV. In Latvijas emigrantu kopienas: Cerību diaspora. Ed. I. Mierina. Rīga: LU FSI, 2015, 161-179.

Sayad, Abdelmalek. The Suffering of the Immigrant. Cambridge: Polity Press, 2004.

Sime, Daniela and Fox, Rachael. Home abroad: Eastern European children's family and peer relationships after migration. Childhood, 22(3), (2015): 377-393.

Sime, Daniela. Belonging and Ontological Security Among Eastern European Migrant Parents and Their Children. Central and Eastern European Migration Review, 7(1), (2018): 35-53.

Skrbiš, Zlatko. Transnational Families: Theorising Migration, Emotions and Belonging. Journal of Intercultural Studies, 29(3), (2008): 231246.

Van Deusen-Scholl, Nelleke. Toward a definition of heritage language: sociopolitical and pedagogical considerations. Journal of Language, Identity \& Education, 2(3), (2003): 211-230. 